\title{
Molecular regulation of luteal progesterone synthesis in domestic ruminants
}

\author{
J. L. Juengel and G. D. Niswender \\ Animal Reproduction and Biotechnology Laboratory, Colorado State University, Fort Collins, \\ CO 80523-1683, USA
}

\begin{abstract}
Regulation of progesterone secretion from the corpus luteum during the oestrous cycle requires the integration of multiple signals to achieve the appropriate amount of progesterone to maximize reproductive efficiency. Development of a mature corpus luteum capable of secreting sufficient amounts of progesterone is dependent upon the pituitary hormones LH and growth hormone $(\mathrm{GH})$. Continued secretion of progesterone from the mature corpus luteum is also dependent upon pituitary hormones. If pregnancy does not occur, prostaglandin $\mathrm{F}_{20}\left(\mathrm{PGF}_{20}\right)$ of uterine origin causes a precipitous decrease in progesterone secretion and demise of the corpus luteum. A major point of regulation of progesterone secretion by both luteotrophic and luteolytic hormones appears to be regulation of transport of cholesterol through the mitochondrial membranes to cytochrome P450scc. It is likely that both luteotrophic and luteolytic hormones regulate steroidogenic acute regulatory protein (StAR), which facilitates transport. Regulation may be occurring through increases or decreases in gene transcription, translation efficiency or post-translational modifications such as phosphorylation. Thus, although synthesis of progesterone is a complex process, both positive and negative regulation of the process appears to occur primarily at a single step (transport of cholesterol to the inner mitochondrial membrane) in the pathway.
\end{abstract}

\section{Introduction}

The corpus luteum, which secretes progesterone, is a transient endocrine gland formed from follicular cells following ovulation. Progesterone is necessary for maintenance of pregnancy in all domestic ruminants. Inadequate luteal secretion of progesterone is a major cause of early embryonic mortality (Nancarrow, 1994; Zavy, 1994). However, if fertilization does not occur, the corpus luteum must stop producing progesterone to allow the complex series of events that results in another ovulation.

In domestic ruminants, the primary luteotrophic hormones, which support the development and function of the corpus luteum, are LH and GH. In addition, locally produced prostaglandins (PG) of the E and I series, and insulin-like growth factors (IGF) probably support luteal function. The luteolytic hormone that causes decreased secretion of progesterone and demise of luteal cells is $\mathrm{PGF}_{2 a}$. This review will focus on how luteotrophic and luteolytic hormones regulate progesterone synthesis at the cellular and molecular levels.

\section{Luteal Steroidogenic Pathway}

For a better understanding of the way in which these hormones regulate secretion of progesterone from the corpus luteum it is first important to understand how steroidogenic cells produce progesterone (Fig. 1). Progesterone is made from the precursor cholesterol. Under normal conditions in vivo, the majority of the cholesterol used for synthesis of all steroid hormones is obtained from high density lipoprotein (HDL) or low density lipoprotein (LDL) (Gwynne and Strauss, 1982). Once 


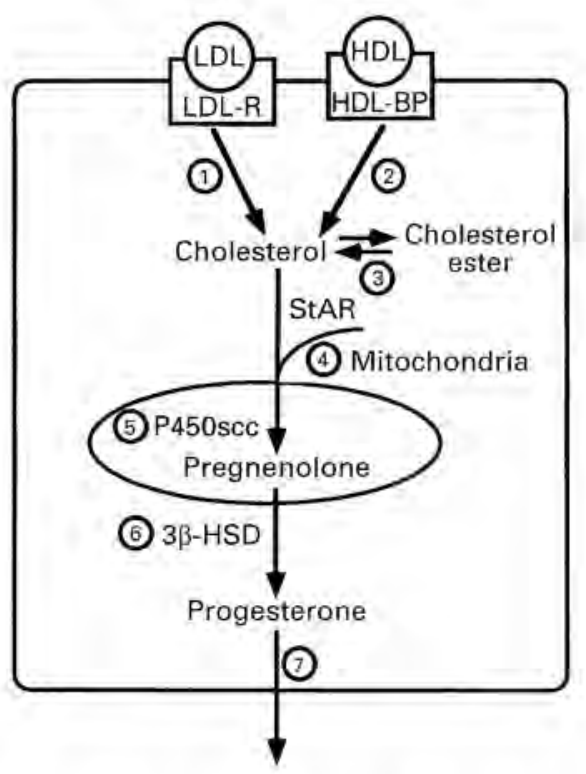

Fig. 1. Pathway of progesterone biosynthesis in a generic luteal cell. Three sources of cholesterol can be utilized for substrate: (1) low density lipoprotein (LDL); (2) high density lipoprotein (HDL); or (3) hydrolysis of stored cholesterol esters by cholesterol esterase. The free cholesterol is transported to the mitochondria apparently with cytoskeletal involvement. Cholesterol is then transported from the outer to inner mitochondrial membrane (4), which appears to involve steroidogenic acute regulatory protein (StAR). Cholesterol is converted to pregnenolone by cytochrome $\mathrm{P} 450$ side-chain cleavage enzyme (P450scc); (5), transported out of the mitochondria and converted to progesterone by 3ß-hydroxysteroid dehydrogenase $/ \Delta^{5}, \Delta^{4}$ isomerase (3 $\beta$-HSD; (6), which is present in the smooth endoplasmic reticulum. Progesterone appears to diffuse from the luteal cell (7).

cholesterol is taken into the cell, it can be shuttled into the steroid biosynthetic pathway or stored as cholesterol esters in the form of lipid droplets (Gwynne and Strauss, 1982). Cholesterol can be released from these stores by cholesterol esterase, when demand for cholesterol exceeds the supply. During steroidogenesis, cholesterol moves through the cytoplasm to the mitochondria, where the side chain is cleaved. This cytoplasmic translocation is dependent upon the cytoskeleton (Jefcoate et al., 1992) and probably involves sterol-binding proteins. Cholesterol must then pass through the outer to the inner mitochondrial membrane where the enzyme complex involved in cholesterol sidechain cleavage is located. Transport of cholesterol across the mitochondrial membranes appears to be the rate-limiting step of steroidogenesis (Stocco and Clark, 1996). It has been proposed that the 
recently identified steroidogenic acute regulatory (StAR) protein facilitates transport of cholesterol to cytochrome P450 side-chain cleavage enzyme ( $\mathrm{P} 450 \mathrm{scc}$ ). The hypothesis that StAR is crucial to transport of cholesterol is supported by several lines of evidence. First, there is preliminary evidence that StAR is capable of binding cholesterol (Liu et al., 1996). Second, StAR has been detected in the inner mitochondrial membrane where cholesterol side-chain cleavage occurs (King et al., 1995). Third, naturally occurring mutations in the StAR gene severely limit steroidogenesis in adrenal and gonadal tissues (Lin et al., 1995). Finally, gonadal tissue collected from patients with mutated StAR protein is capable of producing normal amounts of steroids if provided with membrane permeable cholesterol analogues which by-pass the usual route of cholesterol transport (Miller, 1996).

Another protein that appears to facilitate transport of cholesterol to the side chain cleavage enzyme complex is the peripheral benzodiazepine receptor (PBR; Papadopoulos et al, 1997a). Targeted deletion of PBR resulted in loss of steroidogenic capacity of Leydig cells, which was restored when the cells were supplied with membrane permeable cholesterol analogues (Papadopoulos et al., 1997b). In addition, PBR appears to associate with a voltage-dependent anion channel (VDAC) and molecular modelling indicates that the PBR-VDAC complex will form a pore permeable to cholesterol which spans the mitochondrial membranes (Papadopoulos et al., 1997a). However, little information is available regarding regulation of this system in luteal tissue and thus, the role of this complex in control of luteal progesterone synthesis in domestic ruminants is not known. Once in the mitochondria, cholesterol is converted to pregnenolone by the side chain cleavage enzyme complex which comprises cytochrome P450scc, adrenodoxin and adrenodoxin reductase proteins. Pregnenolone is then converted to progesterone by $3 \beta$-hydroxysteroid dehydrogenase $/ \Delta^{5}, \Delta^{4}$ isomerase ( $3 \beta$-HSD) in the smooth endoplasmic reticulum.

\section{Steroidogenic Cells of the Corpus Luteum}

The corpus luteum contains at least two types of steroidogenic cell that differ in morphological as well as biochemical characteristics. In mature ovine luteal tissue, small luteal cells are 8-22 $\mu \mathrm{m}$ in diameter, have lipid droplets, abundant smooth endoplasmic reticulum and are spindle shaped (Niswender et $\left.a L_{2}, 1985\right)$. These cells have receptors for $\mathrm{LH}$ and respond to this hormone with a 6-12fold increase in steroid production (Fitz et al., 1982; Alila et al., 1988a). Treatment of small luteal cells with $\mathrm{PGI}_{2}$ also increases progesterone synthesis (Fitz et al., 1984; Alila et al., 1988b). In the ewe, small luteal cells do not have high-affinity receptors for $\mathrm{PGF}_{2 \alpha}$ or PGE (Fitz et al., 1982); however, in the cow, mRNA encoding $\mathrm{PGF}_{2 a}$-receptor (Mamluk et al., 1998) as well as $\mathrm{PGF}_{2 \alpha}$ and $\mathrm{PGE}_{2}$ (Chegini et al., 1991) binding sites have been detected in small luteal cells.

Large luteal cells are more spherical, greater than $22 \mu \mathrm{m}$ in diameter, contain abundant quantities of smooth and rough endoplasmic reticulum, have protein containing secretory granules and in cows, but not sheep, contain lipid droplets (Niswender et al., 1985). Although large luteal cells contain receptors for LH (Harrison et al., 1987; Chegini et al., 1991), binding of LH to its receptor does not increase secretion of progesterone from these cells (Rodgers et al., 1983; Hoyer et al., 1984; Alila et al., 1988a). Large luteal cells also contain receptors for prostaglandins $\mathrm{F}_{2 \alpha^{\prime}} \mathrm{E}_{2}$ and $\mathrm{I}_{2}$ (Fitz et al., 1982; Chegini et al., 1991) as well as GH (Lucy et al., 1993) and IGF-I (Perks et al., 1995). Basal secretion of progesterone is 10-40 fold higher in large than in small cells but treatment with stimulatory hormones, such as $\mathrm{PGE}_{2}$ or $\mathrm{PGI}_{2}$ only increases secretion of progesterone from ovine large luteal cells 2-4 fold (Fitz et al., 1984). Prostaglandin $\mathrm{F}_{2,0}$ decreases secretion of progesterone from these cells (Wiltbank et al, , 1991). It has been calculated that the majority of the progesterone $(<80 \%)$ secreted from the mature ovine corpus luteum is derived from large luteal cells (Niswender et al., 1985) although this may be controversial (Rodgers et al $t_{+}$1983).

\section{Regulation of Progesterone Secretion During the Oestrous Cycle}

Changes in the concentration of progesterone in sera normally observed during the oestrous cycle are due to changes in luteal blood flow, size and number of steroidogenic cells and changes in the 


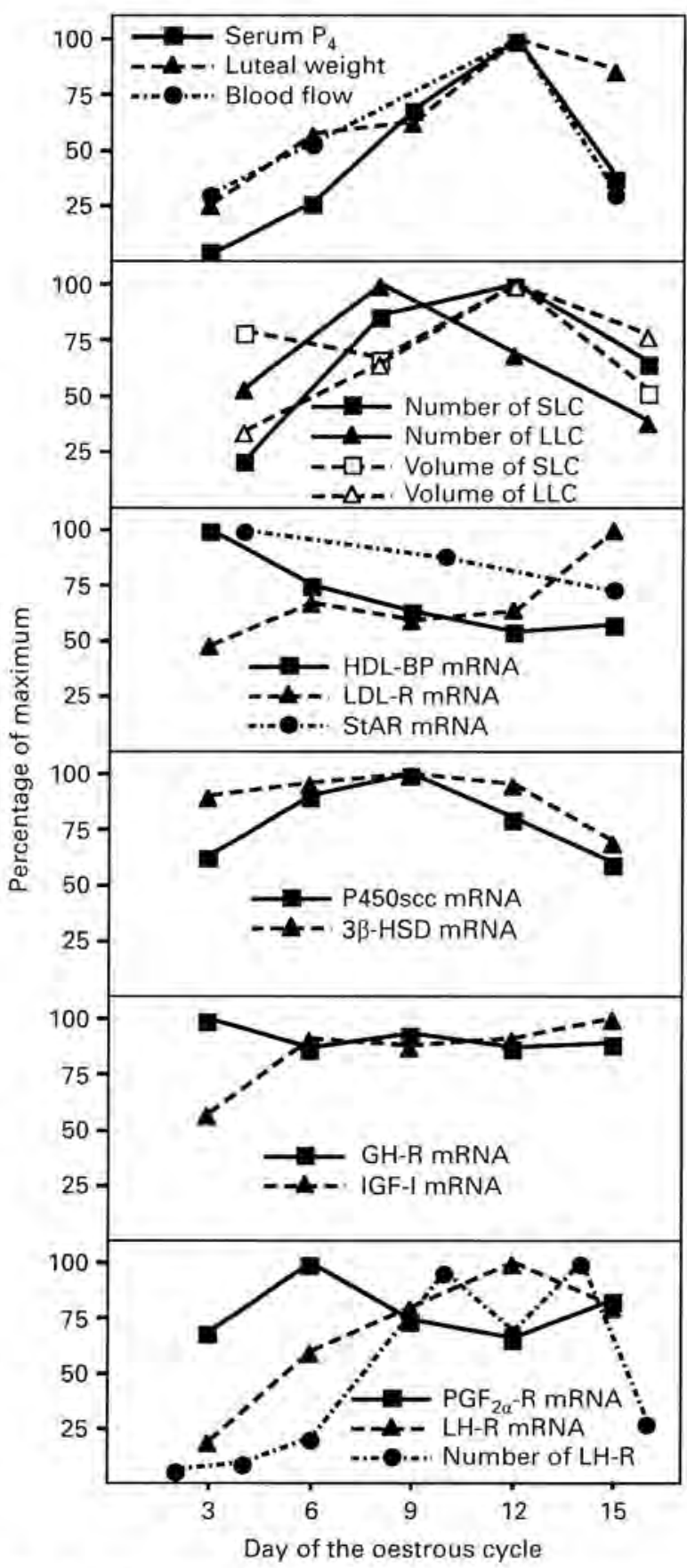

Fig. 2. Changes in concentrations of progesterone in sera (serum $\mathrm{P}_{4}$ ), luteal weight, blood flow to the ovary bearing a corpus luteum, and numbers and sizes of small (S) and large (L) luteal cells (LC) over the ovine oestrous cycle are presented in the top two panels. Changes in mRNA encoding proteins important for cholesterol uptake and transport to the mitochondria (high density lipoprotein- 
steroidogenic capacity of luteal cells (Fig. 2). Increases in concentrations of progesterone in sera during the early luteal phase are paralleled by increases in blood flow (Niswender et al., 1976), luteal weight and numbers and sizes of steroidogenic luteal cells (Fig. 2; Farin et al,, 1986). In contrast, mRNAs encoding many proteins important for steroidogenesis are already expressed at high concentrations by day 3 of the ovine oestrous cycle (Fig. 2; Juengel et al., 1994, 1995a; Tandeski et al., 1996). For this communication, data regarding mRNA encoding important proteins that regulate the functions of luteal cells are expressed, in all cases, as steady-state concentrations. Although the total amount of mRNA encoding most of these proteins in the corpus luteum would increase as the numbers and size of steroidogenic cells increase during luteal development, it is the concentrations of each species of mRNA versus other mRNAs which should control the activity of individual cells. Therefore, steady-state concentrations of mRNA should reflect the ability of an individual mRNA to influence cellular function. It does not appear that expression of any of these mRNAs severely limits secretion of progesterone during the early luteal phase.

Both mRNA and the numbers of receptors for LH (LH-R) increase as luteal development progresses (Fig. 2, Diekman et al., 1978a; Spicer et al., 1981; Garverick et al., 1985; Guy et al., 1995). Thus, it is possible that cellular growth and division and increased progesterone secretion are driven by increasing the responsiveness of individual cells to $\mathrm{LH}$. Progesterone increases expression of LH$\mathrm{R}$ in luteal cells from bovine corpora lutea collected during the early luteal phase (Jones et al, 1992). In addition, luteal concentrations of mRNA encoding IGF-I, IGF-II and the receptor for IGF-I increase during luteal development (Einspanier et al., 1990; Perks et al., 1995; Juengel et al., 1997b) providing additional potential mechanisms for hormonal support of normal luteal growth. During luteal regression, the decrease in concentrations of progesterone in serum is closely associated with reduced blood flow to the corpus luteum (Niswender et al., 1976) and decreased steroidogenic capacity of luteal cells (McGuire et al., 1994; Juengel et al., 1995a; Tandeski et al., 1996). The number of steroidogenic cells decreases later during luteal regression (Braden et al., 1988) and is not associated with the acute downregulation of progesterone synthesis seen during luteal regression. The focus of the remainder of this review will be regulation of steroidogenic capacity of luteal cells as well as their ability to respond to luteotrophic and luteolytic hormones.

\section{Acquisition of maximum steroidogenic capability}

The preovulatory LH surge causes release of the oocyte from the follicle and differentiation of follicular cells into luteal cells (luteinization). Luteinization is characterized by increased steroid production and a switch from producing oestradiol to progesterone. Not surprisingly concentrations of LDL-R, StAR, P450scc and 3 $\beta$-HSD increase during this time (mRNA, protein, or both; Rodgers et al., 1986, 1987; Couet et al., 1990; Voss and Fortune, 1993a; Juengel et al., 1994; Pescador et al., 1996). In addition, enzymes important for oestrogen synthesis (aromatase and $17 \alpha$-hydroxylase cytochrome P450) were greatly decreased in the newly formed bovine corpus luteum (Rodgers et al., 1986, 1987; Voss and Fortune, 1993b). Cells also become more responsive to LH (Diekman et al., 1978a) and GH (Lucy et al., 1993). Receptors for $\mathrm{PGF}_{2 \alpha}$ also increase during luteinization to reach maximum numbers per large luteal cell shortly after ovulation (Wiltbank et al., 1995). Thus, during luteinization, the newly formed corpus luteum gains increased ability to synthesize progesterone and respond to regulatory hormones.

binding protein (HDL-BP); low density lipoprotein-receptor (LDL-R) and steroidogenic acute regulatory protein (StAR)) are shown in the third panel, whereas patterns of expression of mRNA encoding cytochrome P450 side-

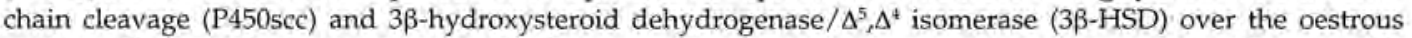
cycle are displayed in the fourth panel. The last two panels contain information about expression of luteotrophic and luteolytic hormones or their receptors (receptor (R) for growth hormone (GH), LH and prostaglandin $F_{2, x}$ $\left(\mathrm{PGF}_{2 a}\right)$ and insulin-like growth factor I (IGF-I)) during the ovine oestrous cycle. Notice the close association between luteal blood flow, luteal weight and amount of progesterone in serum. Data obtained from Niswender et al., 1976; Diekman et al., 1978a; Farin et al., 1986; Juengel et al., 1994, 1995a, 1996, 1997b; Guy et al., 1995 and Tandeski et al, 1996. 
The corpus luteum continues to secrete increasing amounts of progesterone for several days following luteinization, and continued development of the corpus luteum is dependent upon pituitary support (Farin et al., 1990; Juengel et al., 1995b). Supply of cholesterol probably does not limit secretion of progesterone from the corpus luteum during development, as steady-state concentrations of mRNA encoding HDL-binding protein (HDL-BP; Tandeski et al., 1996) and LDL-R (Rodgers et al., 1987; Tandeski et al., 1996) were maximal early in the oestrous cycle (Fig. 2), and hypophysectomy of ewes did not decrease expression of these mRNAs (Tandeski et al., 1996). Steady-state concentrations of mRNA encoding StAR or StAR protein also peak early in the oestrous cycle (Juengel et al, 1995a; Pescador et al., 1996). However, removal of pituitary support during luteal development severely reduces mRNA encoding StAR and replacement of LH or GH prevented this decrease (Juengel et al, 1995a). Thus, expression of normal amounts of mRNA encoding StAR, and presumably protein since these two variables are highly correlated (Pescador et al., 1996), appears essential for maximal secretion of progesterone. Conversion of cholesterol to pregnenolone by the $\mathrm{P} 450 \mathrm{scc}$ enzyme complex may limit secretion of progesterone during development of the corpus luteum as mRNA, or protein, or both for P450scc and adrenodoxin increase during luteal development (Rodgers et al., 1986; 1987; Juengel et al., 1994). Removal of the pituitary gland prevents the normal increases in mRNA encoding P450scc observed during the ovine oestrous cycle, and replacement of LH or GH supports normal expression of this mRNA (Juengel et al., 1995b). Conversion of pregnenolone to progesterone by $3 \beta$-HSD does not appear to limit secretion of progesterone from the corpus luteum. Concentrations of mRNA encoding $3 \beta-H S D$, as well as $3 \beta$-HSD protein and enzyme activity reach maximum values early in the oestrous cycle and appear to be in great excess (Couet et al., 1990; Wiltbank et al.; 1993; Juengel et al., 1994). In addition, maximal expression of $3 \beta-H S D$ mRNA, which is dependent upon $\mathrm{LH}$, was not required for maximal secretion of progesterone (Juengel et al., 1995b).

The increase in the number of receptors for LH observed during luteal development (Diekman et al., 1978a; Spicer et al., 1981, Garverick et al., 1985) was preceded by an increase in mRNA encoding this receptor (Guy et al., 1995). However, removal of the pituitary gland during luteal development did not prevent expression of normal concentrations of LH-R in luteal tissue (Farin et al., 1990; Juengel et al., 1995b). Thus, reduced expression of the LH-R was not limiting secretion of progesterone in hypophysectomized ewes. In contrast, while mRNA encoding the receptor for GH (GH-R) is expressed at maximal concentrations in corpora lutea by day 3 of the ovine oestrous cycle, removal of the pituitary gland caused a decrease in expression of this mRNA (Juengel et al., 1997b). Somewhat surprisingly, LH, but not GH, supported normal expression of GH-R mRNA (Juengel et al., 1997b). However, concentrations of progesterone in sera of $\mathrm{GH}$-treated, hypophysectomized ewes were not different from those in pituitary-intact control ewes. Thus, secretion of progesterone in hypophysectomized ewes was not probably limited by a lack of GH binding. Similarly, although concentrations of mRNA encoding IGF-I increase during luteal development, this increase in expression of IGF-I mRNA was not necessary for normal progesterone biosynthesis (Juengel et al., $1997 \mathrm{~b})$. In contrast, increases in luteal weight were associated with increased expression of IGF-I mRNA (Juengel et al., 1997b). Thus, concentrations of progesterone in sera are not tightly linked to luteal expression of IGF-I mRNA, but increases in luteal weight were associated with increases in this mRNA.

\section{Maintenance of maximal steroidogenic capacity}

Once the corpus luteum is fully formed, it does not appear to require pulsatile LH release to maintain secretion of progesterone at normal, mid-luteal phase values in either sheep or cattle (McNeilly et al., 1992; Peters et al., 1995). However, basal amounts of LH are necessary to maintain normal serum concentrations of progesterone and luteal weights in sheep (Haworth et al., 1998). An additional pituitary hormone may also be necessary for normal luteal function during the mid-luteal phase, as hypophysectomy decreased concentrations of progesterone in sera and luteal weights more severely than specific removal of LH with an antiserum (Haworth et al., 1998). Both specific 
removal of LH and hypophysectomy decreased luteal weight and luteal concentrations of mRNAs encoding StAR, P450scc and 36-HSD (Haworth et al., 1998). Thus, removal of the pituitary decreases both the amount of Iuteal tissue and the capability of that tissue to synthesize progesterone. However, since hypophysectomy during the mid-luteal phase only reduced concentrations of progesterone in sera 4 days later by approximately $60 \%$ (Haworth et al., 1998), it seems likely that the corpus luteum of the ewe is somewhat independent of pituitary support at this time.

\section{Cellular regulation of enhanced synthesis of progesterone}

In small luteal cells, $\mathrm{LH}$-induced increases of progesterone synthesis were associated with a slight increase in release of cholesterol from cholesterol esters but not with increased uptake of

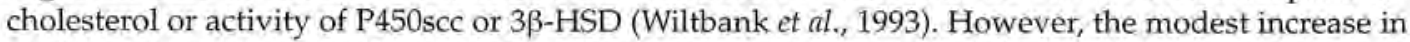
cholesterol esterase activity was not sufficient to account for the marked increase in progesterone secretion in these cells. Therefore, it was postulated that LH was increasing transport of cholesterol through the cell or across the mitochondrial membranes. Since StAR facilitates the transport of cholesterol to P450scc (Stocco and Clark, 1996), regulation of this molecule appears to be crucial in control of secretion of progesterone. Chronic removal of LH decreases concentrations of mRNA encoding StAR (Juengel et al., 1995a); however, whether LH acutely increases luteal concentrations of StAR mRNA is not clear. Intra-ovarian infusion of LH did not increase steady-state concentrations of mRNA encoding StAR 4, 12 or $24 \mathrm{~h}$ later (Juengel et al., 1997a); thus, if LH acutely increases luteal concentrations of StAR mRNA it must do so in a very rapid and transient manner. However, a direct effect of activation of PKA on transcription of the StAR gene has been demonstrated as the human (Sugawara et al., 1997), mouse (Caron et al., 1997) and sheep (J. L. Juengel, C. M. Clay and G. D. Niswender; unpublished observations) StAR promoters respond directly to PKA activation with modest increases in activity. In addition, the ability of StAR to stimulate steroidogenesis was increased by PKA-dependent phosphorylation (Arakane et al., 1997). Thus, the acute luteotrophic effects of LH are probably due to increased transcription, translation or phosphorylation of StAR.

Other hormones such as $\mathrm{PGE}_{2}$ (Fitz et al., 1984; Alila et al., 1988b), PGI (Fitz et al., 1984; Alila et al., 1988b), GH (Liebermann and Schams, 1994) and IGF-I (McArdle and Holtorf, 1989) have also been shown to increase secretion of progesterone from luteal cells; however, the mechanisms by which these hormones stimulate progesterone synthesis are not known. Prostaglandin $\mathrm{E}_{2}$ and $\mathrm{I}_{2}$ have been reported to increase cAMP (Marsh, 1975; Bennegard et al., 1990) and thus, in small luteal cells, would be expected to increase progesterone secretion in a manner similar to LH. However, both of these hormones also increase progesterone synthesis in large luteal cells (Fitz et al., 1984; Alila et al., 1988b), which do not respond to increased cAMP with an increase in progesterone secretion (Fitz et al., 1984; Hoyer et al., 1984). Therefore, binding of these hormones to receptors in large luteal cells must regulate progesterone secretion in another manner. A better understanding of how both basal and luteotropin stimulated progesterone synthesis is controlled in small, and particularly, large luteal cells is crucial if these processes are to be manipulated effectively.

\section{Cellular regulation of reduced secretion of progesterone}

Progesterone secretion is maintained for several days, and then rapidly declines if pregnancy does not occur. This rapid decline in the concentration of progesterone in sera is followed by a slower decrease in luteal weight. Prostaglandin $\mathrm{F}_{2 \alpha}$ induces both the rapid decrease in progesterone secretion and loss of luteal tissue (Niswender and Nett, 1994). Binding of $\mathrm{PGF}_{20}$ to its receptor causes activation of PKC and an influx of calcium (Wiltbanket al., 1991). Pharmacological activation of PKC in vivo decreases secretion of progesterone without causing luteal cell death (McGuire et al., 1994). Similarly, a low dose of $\mathrm{PGF}_{2 a^{\prime}}$ which transiently decreased secretion of progesterone and induced oligonucleosome formation, does not cause luteolysis (J. L. Juengel, J. D. Haworth, M. K. Rollyson, P. J. Silvia, E. W. McIntush, H. R. Sawyer and G. D. Niswender, unpublished observations). Thus, destruction of the corpus luteum is not required for reduced progesterone secretion from this tissue. 
In fact, it seems clear that the anti-steroidogenic effects of $\mathrm{PGF}_{2 \pi \mathrm{r}}$ are mediated via the PKC second messenger pathway, while the cytotoxic effects are mediated via calcium influx (Wiltbank et al., 1991).

Some mechanisms whereby activation of PKC by $\mathrm{PGF}_{2 \pi}$ could decrease synthesis of progesterone at the cellular level include (1) influencing uptake or transport of cholesterol, (2) regulating conversion of cholesterol to pregnenolone or pregnenolone to progesterone, or (3) reducing the ability of the corpus luteum to respond to luteotrophic hormones by reducing receptors for $\mathrm{LH}$, GH or both hormones, or interfering with the ability of the hormone receptor complex to activate their second messenger systems. The cellular mechanisms by which $\mathrm{PGF}_{2 n}$ decreases synthesis of progesterone are rapidly being elucidated.

Treatment of ewes with PGF ${ }_{2 \pi}$ decreased concentrations of mRNA encoding LDL-R; however, concentrations of HDL-BP mRNA actually increased during the first $12 \mathrm{~h}$ after treatment with PGF $_{2 a}$ (Fig. 3; Tandeski et al., 1996). Suppression of LDL-R mRNA to values similar to those seen after treatment with $\mathrm{PGF}_{2 \alpha}$ did not affect secretion of progesterone (T.R. Tandeski, J. L. Juengel, and G, D, Niswender, unpublished observations). Therefore, it seems unlikely that suppression of LDL-R mRNA is important for reduced secretion of progesterone during luteolysis. Furthermore, lipoprotein uptake was not limiting progesterone secretion in cultures of either ovine or bovine luteal cells after treatment with $\mathrm{PGF}_{2 \mathrm{ce}}$ (Grusenmeyer and Pate 1992; Wiltbank et al., 1993). Finally, treatment of ovine luteal cells with $\mathrm{PGF}_{2 a}$ did not affect release of cholesterol from cholesterol esters (Wiltbank et al., 1993). Thus, $\mathrm{PGF}_{2 \alpha}$ does not appear to reduce synthesis of progesterone by decreasing the availability of cholesterol for steroidogenesis.

In cultures of ovine and bovine luteal cells, $\mathrm{PGF}_{2 n}$ appeared to decrease transport of cholesterol through the cytoplasm, or from the outer to inner mitochondrial membrane, or both (Grusenmeyer and Pate 1992; Wiltbank et al., 1993). Transport of cholesterol through the cell to the mitochondria is facilitated by the cytoskeleton (Jefcoate et al., 1992) and disruption of the cytoskeleton will decrease secretion of progesterone from luteal cells (Niswender and Nett, 1994). Treatment of ewes with $\mathrm{PGF}_{2 c t}$ rapidly disrupts the microtubular network of ovine corpora lutea (Murdoch, 1996). This disruption occurred before concentrations of progesterone in sera or luteal tissues decreased (Murdoch, 1996). In addition, in rat corpora lutea, administration of $\mathrm{PGF}_{2 \alpha}$ rapidly decreases concentrations of sterol carrier protein-2 (SCP-2), which facilitates transport of cholesterol through the cytoplasm (McLean et al., 1995). Whether PGF $_{2 \alpha}$ has a similar effect on SCP-2 in luteal tissue of domestic ruminants is not known. Thus, one mechanism that $\mathrm{PGF}_{2 \alpha}$ may use to reduce progesterone synthesis is disruption of cholesterol transport to the mitochondria.

Prostaglandin $\mathrm{F}_{2 \alpha}$ also appears to disrupt transport of cholesterol across the mitochondrial membranes, potentially through regulation of StAR. Concentrations of StAR mRNA or protein in ovine and bovine corpora lutea were reduced within $12 \mathrm{~h}$ of treatment with PGF $_{2 \alpha}$ (Fig. 3; Juengel et al., 1995a; Pescador et al., 1996). In addition, since the activity of StAR is modified by phosphorylation (Arakane et al., 1997), and StAR contains several potential PKC phosphorylation sites (Hartung et al., 1995; J. L. Juengel and G. D. Niswender, unpublished observations), its activity may be modified by $\mathrm{PGF}_{2 \alpha}$ to reduce progesterone synthesis more rapidly. Of particular interest are three potential PKC phosphorylation sites in the mitochondrial targeting sequence, the modification of which could be proposed to prevent targeting of StAR to the mitochondria. However, removal of the mitochondrial targeting sequence did not appear to affect the ability of StAR to stimulate steroidogenesis (Arakane et al., 1996). It should be pointed out that marked over-expression of the mutated form of StAR without its mitochondrial targeting sequence may have saturated the normal cholesterol transport mechanisms. Thus, the potential for modifications of the mitochondrial targeting sequence of StAR to interfere with cholesterol transport is unclear. The PBR system has been shown to be essential for transport of cholesterol to P450scc in other steroidogenic cells (Papadopoulus et al., 1997b); however, little is known about its potential regulation in luteal tissue of domestic ruminants. Thus, whether $\mathrm{PGF}_{2 n}$-induced downregulation of progesterone synthesis is mediated partially through regulation of the PBR system remains to be determined. It is clear that one of the mechanisms by which $\mathrm{PGF}_{2 a}$ decreases synthesis of progesterone in luteal cells is disruption of transport of cholesterol across the mitochondrial membranes.

For some time, conversion of cholesterol to pregnenolone was thought to be the rate-limiting 


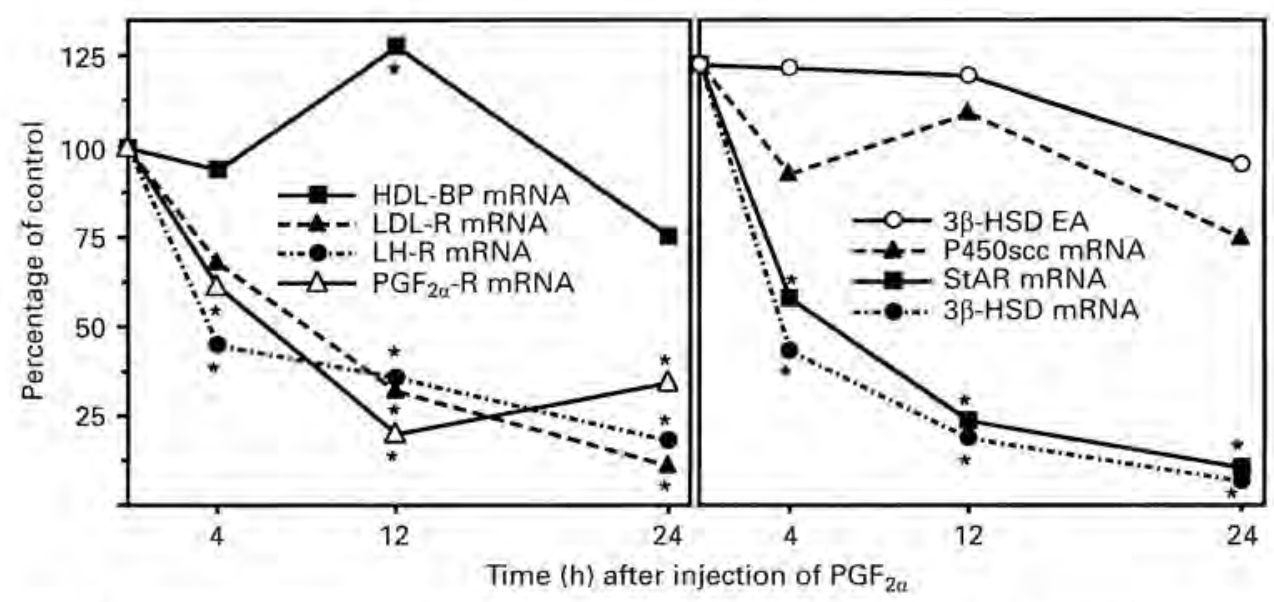

Fig. 3. Pattern of expression of mRNA encoding high density lipoprotein-binding protein (HDL-BP), low density lipoprotein-receptor (LDL-R), luteinizing hormone-receptor ( $\mathrm{LH}-\mathrm{R})$ and prostaglandin $\mathrm{F}_{2 \mathrm{~s}}$-receptor $\left(\mathrm{PGF}_{2 \mathrm{~g}}-\mathrm{R}\right) 4,12$ and $24 \mathrm{~h}$ after injection of $\mathrm{PGF}_{2 \alpha}$ are shown in the left panel. Values are expressed as a percentage of the control value. Pattern of expression of mRNA encoding steroidogenic acute regulatory protein (StAR), cytochrome $\mathrm{P} 450$ side-chain cleavage enzyme

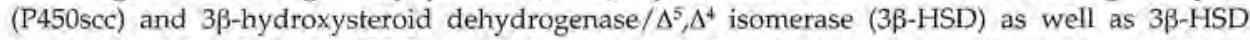
enzyme activity (EA) after $\mathrm{PGF}_{2 \alpha}$ administration are given in the right panel. Within a variable, values that differ $(P<0.05)$ from controls (time of injection) are indicated with an asterisk. Data obtained from Guy et al. 1995; Juengel et al., 1995a, 1996, 1998; and Tandeski et al., 1996.

step in steroid synthesis. However, the activity, protein concentration and concentrations of mRNA encoding P450scc are not acutely reduced following treatment with $\mathrm{PGF}_{2 n}$ (Fig. 3; Grusenmeyer and Pate, 1992; Wiltbank et al., 1993; McGuire et al., 1994; Tian et al, 1994; Rodgers et al,, 1995). Thus, reduced progesterone synthesis is not due to a decreased capacity to convert cholesterol to pregnenolone. Induction of luteolysis with $\mathrm{PGF}_{2 \alpha}$ rapidly decreased mRNA encoding $3 \beta-\mathrm{HSD}$ in both ewes and cows (McGuire et al., 1994; Tian et al., 1994). However, in the same tissue that had

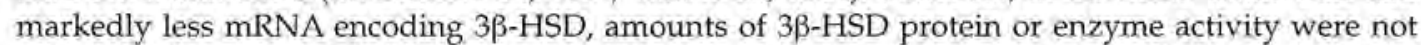
reduced (Fig. 3; Rodgers et al., 1995; Juengel et al., 1998). Thus, PGF $_{2 e}$-induced downregulation of luteal progesterone secretion does not appear to be mediated by decreased ability to convert pregnenolone to progesterone.

Administration of $\mathrm{PGF}_{2 \alpha}$ did not decrease concentrations of mRNA encoding GH-R or IGF-I (Juengel et al., 1997b). In fact, IGF-I mRNA and protein increased during the later stages of luteolysis (Perks et al., 1995). Binding of IGF-I to luteal tissue has also been shown to increase during luteolysis; however, this appeared to be due to increased expression of IGF-I binding proteins and not to an increased number of IGF-I receptors (Perks et al., 1995). Since IGF-I binding proteins can decrease IGF-I availability, decreased free IGF-I may be important in luteolysis. Injection of PGF $_{2 a}$ decreased mRNA encoding LH-R (Fig. 3; Guy et al., 1995); however, numbers of LH receptors were not decreased until after concentrations of progesterone in sera had declined (Diekman et al., 1978b; Spicer et al., 1981). Thus, the decrease in progesterone secretion following PGF $_{2 \pi t}$ is not likely due to an inability of the corpus luteum to respond to tropic hormonal stimuli; however, PGF $_{2 a}$ could affect the ability of the hormone-receptor complex to activate its second messenger. Indeed, PGF $2 \alpha$ decreases adenylate cyclase activity and increases phosphodiesterase, thus decreasing the amount of cAMP available to activate PKA (Agudo et al., 1984; Garverick et al., 1985) which would decrease secretion of progesterone particularly from small luteal cells.

One of the most interesting aspects of the changes that occur after $\mathrm{PGF}_{2 \alpha}$ treatment of ewes is the

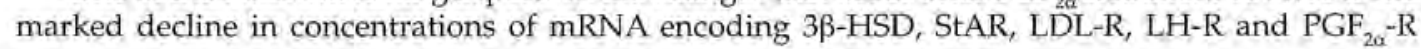




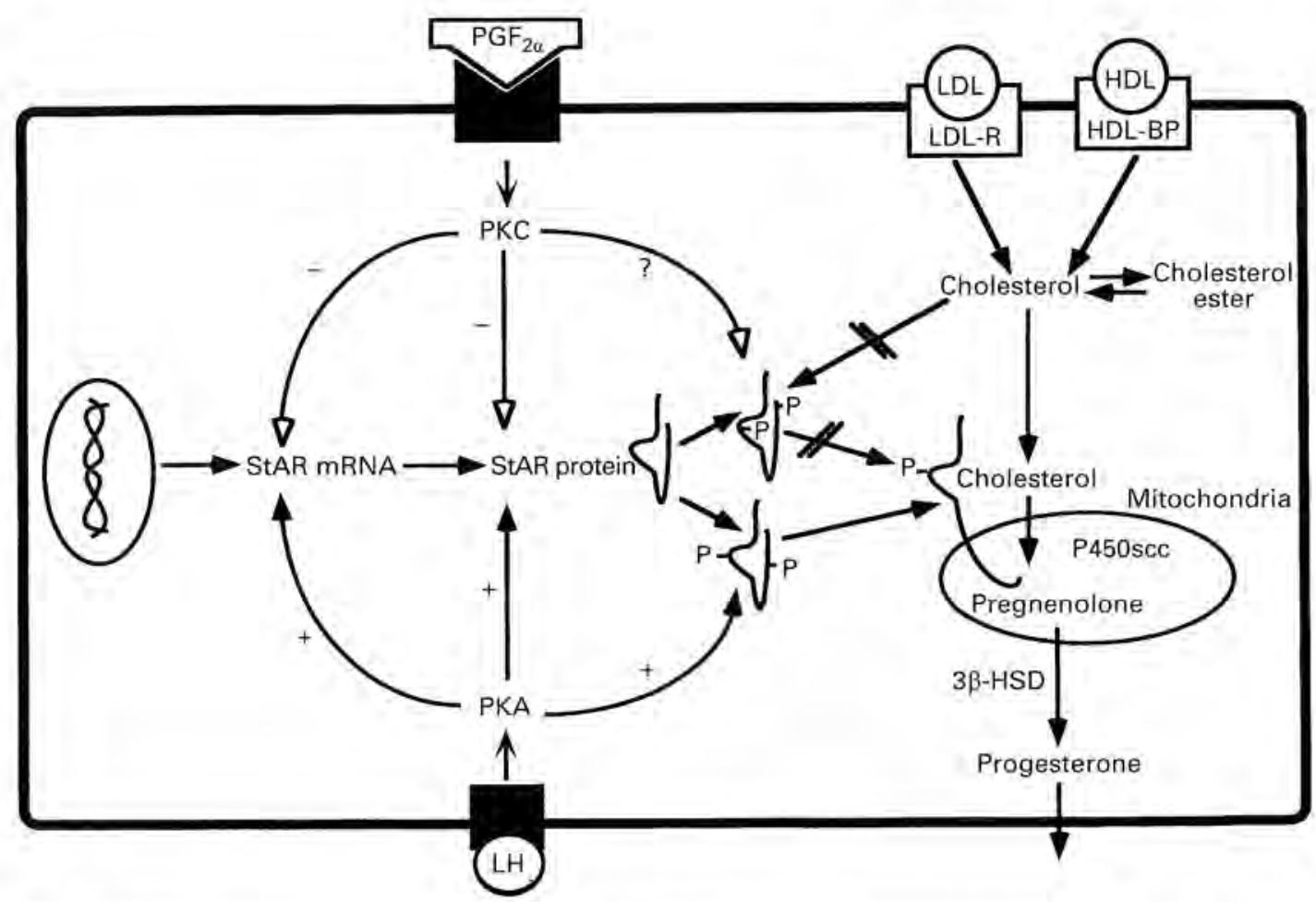

Fig. 4. Potential mechanisms by which $\mathrm{LH}$ and prostaglandin $\mathrm{F}_{2 u}\left(\mathrm{PGF}_{2 \alpha}\right)$ regulate steroidogenic acute regulatory protein- (StAR) facilitated transport of cholesterol to cytochrome P450 side-chain cleavage enzyme (P450scc). Binding of $\mathrm{LH}$ to its receptor activates protein kinase A (PKA), which increases mRNA encoding StAR through transcriptional activation of the StAR gene but not through stabilization of the StAR mRNA (Kiriakidou et al., 1996). Increases in mRNA encoding StAR, and potentially increased translational efficiency of the StAR mRNA, would increase the amount of StAR protein. In addition, PKA phosphorylates StAR thereby increasing its ability to transport cholesterol to cytochrome P450scc. The anti-steroidogenic effects of PGF, have been shown to be mediated through activation of protein kinase $\mathrm{C}$ (PKC). Prostaglandin $\mathrm{F}_{2 \alpha}$ decreases steady-state conçentrations of mRNA encoding StAR, potentially by decreasing transcription of the StAR gene, destabilizing the StAR mRNA, or by both mechanisms. Concentrations of StAR protein decrease and it is possible that activity of the StAR protein is reduced through post-translational modifications, such as phosphorylation, resulting in decreased ability to bind cholesterol or decreased StAR-facilitated transport of cholesterol to P450scc. In addition, activation of PKC decreases cAMP concentrations, thus potentially reducing the PKA-activated increases in StAR activity. LDL-R: Iow density lipoprotein receptor; HDL-BP: high density lipoprotein-binding protein; $3 \beta-H S D$ : $3 \beta$-hydroxysteroid dehydrogenase $/ \Delta^{5}, \Delta^{4}$ isomerase.

while concentrations of mRNA encoding HDL-BP and P450scc were unaffected (Fig. 3). This may indicate that a very specific mechanism is activated by the PKC second messenger pathway which results in enhanced degradation or inhibited synthesis of some mRNAs with no effect on others. This mechanism may be specific to luteal cells as activation of PKC in other steroidogenic cell types has very different effects on several of the mRNAs encoding steroidogenic proteins.

\section{Conclusion}

Development and maintenance of the steroidogenic machinery in luteal cells is dependent upon pituitary hormones, LH and GH. These hormones not only support increases in luteal weight but 


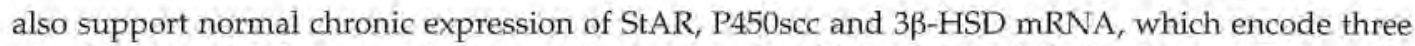
proteins essential for progesterone synthesis. Luteotrophic and luteolytic hormones also acutely regulate progesterone synthesis. The primary effect of $\mathrm{LH}$ appears to be regulation of pregnenolone production by increasing transport of cholesterol to cytochrome P450scc. One protein likely to facilitate this process is StAR. The precise mechanisms by which StAR facilitates transport of cholesterol to cytochrome P450scc are not known. However, phosphorylation of StAR by PKA is likely one mechanism by which LH acutely enhances the activity of StAR and thus progesterone synthesis (Fig. 4). In addition, activation of PKA may also increase transcription of the StAR gene, or increase translation efficiency of StAR mRNA (or both), thereby increasing the amount of StAR protein available to facilitate transfer of cholesterol (Fig. 4). Prostaglandin $\mathrm{F}_{2 \alpha}$ reduces transport of cholesterol across the mitochondrial membranes, potentially by decreasing amounts of StAR protein or its ability to transport cholesterol. Prostaglandin $\mathrm{F}_{2 \Omega}$ may reduce StAR protein by decreasing transcription of the StAR gene, interfering with stability of the StAR transcript or reducing translation efficiency of the StAR mRNA (Fig. 4). Once StAR is inserted into the mitochondria, it is likely that it is no longer able to transport cholesterol. Therefore, only newly synthesized protein transports cholesterol giving StAR an effective half life of 3-5 min. Thus, one mechanism that both luteotrophic and luteolytic hormones appear to use to regulate progesterone secretion from the corpus luteum acutely is regulation of StAR-facilitated transport of cholesterol. This may be accomplished through regulation of transcription of the StAR gene, stability of the StAR mRNA, synthesis of StAR protein, or post-translational modifications of StAR such as phosphorylation (Fig. 4).

This research was supported by NIH grant HD 11590 and the Colorado Agricultural Experiment Station. The authors appreciate the invaluable technical expertise of M. Gallegos, B. Meberg, C. Moeller and K. Sutherland. They would also like to thank Kathy Thomas for her assistance with preparation of manuscripts.

\section{References}

Agudo SPL, Zahler WL and Smith MF (1984) Effects of prostaglandins $\mathrm{F}_{2 \mathrm{ix}}$ on the adenylate cyclase and phosphodiesterase activity of ovine corpora lutea joumal of Animal Science 58 955-962

Alila HW, Dowd JP, Corradino RA, Harris WV and Hansel W (1988a) Control of progesterone production in small and large bovine luteal cells separated by flow cytometry Journal of Reproduction and Fertility 82 645-655

Alila HW, Corradino RA and Hansel W (1988b) A comparison of the effects of cyclooxygenase prostanoids on progesterone production by small and large bovine luteal cells Prostaglandins $36259-270$

Arakane E, Sugawara T, Nishino H, Liu Z, Holt JA, Pain D, Stocco DM, Miller WL and Strauss JF III (1996) Steroidogenic acute regulatory protein (StAR) retains activity in the absence of its mitochondrial import sequence: implications for the mechanism of StAR action Proceedings of the National Academy of Sciences USA 9313 731-13 736

Arakane F, King SR, Du $X$, Kallen CB, Walsh LP, Watari H, Stocco DM and Strauss JF, III (1997) Phosphorylation of steroidogenic acute regulatory protein (StAR) modulates its steroidogenic activity Journal of Biological Chemistry 272 $32656-32662$

Bernegard B, Hahlin M and Hamberger L (1990) Luteotrophic effects of prostaglandins $I_{2}$ and $D_{2}$ on isolated human corpora lutea Fertility and Sterility 54 459-464

Braden TD, Gamboni F and Niswender GD (1988) Effects of prostaglandin $\mathrm{F}_{20}$-induced luteolysis on the populations of cells in the ovine corpus lutea Biology of Reproduction 39 245-253

Caron KM, Ikeda Y, Soo S-C, Stocco DM, Parker KL and Clark BJ
(1997) Characterization of the promoter region of the mouse gene encoding the steroidogenic acute regulatory protein Molecular Endocrinology 11 138-147

Chegini N, Lei ZM, Rao Ch V and Hansel W (1991) Cellular distribution and cycle phase dependency of gonadotropin and eicosanoid binding sites in bovine corpora lutea Biology of Reproduction 45 506-513

Couet J, Martel C, Dupont E, Luu-The V, Sirard M-A, Zhao H-E, Pelletier G and Labrie F (1990) Changes in $3 \beta$ hydroxysteroid dehydrogenase $/ \Delta^{5}-\Delta^{4}$ isomerase messenger ribonucleic acid, activity and protein levels during the estrous cycle in the bovine ovary Endocrinology $1272141-2148$

Diekman MA, O'Callaghan P, Nett TM and Niswender GD (1978a) Validation of methods and quantification of luteal receptors for $\mathrm{LH}$ throughout the estrous cycle and early pregnancy in ewes Biology of Reproduction 19 999-1009

Diekman MA, O'Callaghan P, Nett TM and Niswender GD (1978b) Effect of prostaglandin $F_{2 \alpha}$ on the number of $\mathrm{LH}$ receptors in ovine corpora lutea Biology of Reproduction 19 1010-1013

Einspanier R, Miyamoto A, Schams D, Muller M and Brem G (1990) Tissue concentration, mRNA expression and stimulation of IGF-I in luteal tissue during the oestrous cycle and pregnancy of cows Fournal of Reproduction and Fertility $90439-445$

Farin CE, Moeller CL, Sawyer HR, Gamboni F and Niswender GD (1986) Morphometric analysis of cell types in the ovine corpus luteum throughout the estrous cycle Biology of Reproduction 35 1299-1308

Farin CE, Nett TM and Niswender GD (1990) Effects of luteinizing hormone on luteal cell populations in 
hypophysectomized ewes lournal of Reproduction and Fertility 88 61-70

Fitz TA, Mayan MH, Sawyer HR and Niswender GD (1982) Characterization of two steroidogenic cell types in the ovine corpus luteum Biology of Reproduction 27 703-711

Fitz TA, Hoyer PB and Niswender GD (1984) Interactions of prostaglandins with subpopulations of ovine luteal cells I. Stimulatory effects of prostaglandins $E^{\prime}, E_{2}$ and $I_{3}$ Prostaglandins 28 119-126

Garverick HA, Smith MF, Elmore RG, Morehouse GL, Agudo SPL and Zahler WL (1985) Changes and interrelationships among luteal $\mathrm{LH}$ receptors, adenylate cyclase activity and phosphodiesterase activity during the bovine estrous cycle Journal of Animal Science 61 216-223

Grusenmeyer DP and Pate IL (1992) Localization of prostaglandins $\mathrm{F}_{2 \mathrm{~s}}$ inhibition of lipoprotein use by bovine luteal cells Journal of Reproduction and Fertility 94 311-318

Guy MK, Juengel JL, Tandeski TR and Niswender GD (1995) Steady-state concentrations of mRNA encoding the receptor for luteinizing hormone during the estrous cycle and following prostaglandin $\mathrm{F}_{20}$ treatment of ewes Endocrime 3 585-589

Gwynne JT and Strauss JF, III (1982) The role of lipoproteins in steroidogenesis and cholesterol metabolism in steroidogenic glands Endocrine Reviews 3 299-329

Harrison LM, Kenny N and Niswender GD (1987) Progesterone production, $\mathrm{LH}$ receptors, and oxytocin secretion by ovine luteal cell types on days 6,10 and 15 of the oestrous cycle and day 25 of pregnancy Journal of Reproduction and Fertility 79 539-548

Hartung S, Rust W, Balvers M and Ivell R (1995) Molecular cloning and in vivo expression of the bovine steroidogenic acute regulatory protein Biochemical and Biophiysical Research Communications 215 646-653

Hoyer PB, Fitz TA and Niswender GD (1984) Hormoneindependent activation of adenylate cyclase in large steroidogenic ovine luteal cells does not result in increased progesterone secretion Endocrinology 114 604-608

Jefcoate CR, McNamara BC, Artemenko I and Yamazaki T (1992) Regulation of cholesterol movement to mitochondrial cytochrome $\mathrm{P} 450 \mathrm{sec}$ in steroid hormone synthesis Journal of Steroid Biochemistry and Molecular Biology 43 751-767

Jones LS, Ottobre JS and Pate JL (1992) Progesterone regulation of luteinizing hormone receptors on cultured bovine luteal cells Molecular and Cellular Endocrinology 85 33-39

Juengel JL, Guy MK, Tandeski TR, McGuire WJ and Niswender GD (1994) Steady-state concentrations of messenger ribonucleic acid encoding cytochrome P450 side-chain cleavage and $3 \beta$-hydroxysteroid dehydrogenase $/ \Delta^{5}, \Delta^{4}$ isomerase in ovine corpora lutea during the estrous cycle Biology of Reproduction 51 380-384

Juengel JL, Meberg BM, Turzillo AM, Nett TM and Niswender GD (1995a) Hormonal regulation of messenger ribonucleic acid encoding steroidogenic acute regulatory protein in ovine corpora lutea Endocrinology $1365423-5429$

Juengel JL, Nett TM, Tandeski TR, Eckery DC, Sawyer HR and Niswender GD (1995b) Effects of luteinizing hormone and growth hormone on luteal development in hypophysectomized ewes Enidocrine 3 323-326

Juengel JL, Wiltbank MC, Meberg BM and Niswender GD (1996) Regulation of steady-state concentrations of messenger ribonucleic acid encoding prostaglandin $F_{2 x}$-receptor in ovine corpus luteum Biology of Reproduction 54 1096-1102

Juengel JL, Larrick TL, Meberg BM and Niswender GD (1997a)
Luteal expression of steroidogenic factor-1 mRNA during the estrous cycle and in response to luteinizing hormone (LH) stimulation Biology of Reproduction 56 (Supplement 1) Abstract 145

Juengel JL, Nett TM, Anthony RV and Niswender GD (1997b) Effects of luteotrophic and luteolytic hormones on expression of mRNA encoding insulin-like growth factor-1 and growth hormone receptor in the ovine corpus luteum Journal of Reproduction and Fertility 110 291-298

Juengel JL, Meberg BM, McIntush EW, Smith MF and Niswender GD (1998) Concentration of mRNA encoding 3\%hydroxysteroid dehydrogenase $/ \Delta^{5}, \Delta^{4}$ isomerase (3B-HSD) and $3 \beta-H S D$ enzyme activity following treatment of ewes with prostaglandin $\mathrm{F}_{2 n}$ Endocrine $845-50$

King SR, Ronen-Fuhrmann T, Timberg R, Clark BJ, Orly J and Stocco DM (1995) Steroid production after in vitro transcription, translation, and mitochondrial processing of protein products of complementary deoxyribonucleic acid for steroidogenic acute regulatory protein Endocrinology $1365165-5176$

Kiriakidou M, McAllister JM, Sugawara T and Strauss JF, III (1996) Expression of steroidogenic acute regulatory protein (StAR) in the human ovary Journal of Clinical Endocrinology and Metabolism $814122-4128$

Liebermann J and Schams D (1994) Actions of somatotrophin on oxytocin and progesterone release from the microdialysed bovine corpus luteum in vitro. Journal of Endocrinology 143 243-250

Lin D, Sugawara T, Strauss JF, III, Clark BJ, Stocco DM, Saenger P, Rogol A and Miller WL (1995) Role of steroidogenic acute regulatory protein in adrenal and gonadal steroidogenesis Science 267 1828-1831

Liu Z, Frolov AA, Schroeder E and Stocco DM (1996) Does cholesterol bind to the steroidogenic acute regulatory (StAR) protein? Biology of Reproduction 54 (Supplement 1) Abstract 194

Lucy MC, Collier RJ, Kitchell ML, Dibner J], Hauser SP and Kriui GG (1993) Immunohistochemical and nucleic acid analysis of somatotropin receptor populations in the bovine ovary Biology of Reproduction 48 1219-1227

McGuire WJ, Juengel JL and Niswender GD (1994) Protein kinase $C$ second messenger system mediates the antisteroidogenic effects of prostaglandin $\mathrm{F}_{2 i t}$ in the ovine corpus luteum in vivo. Biology of Reproduction 51 800-806

McLean MP, Billheimer JT, Warden KJ and Irby RB (1995) Prostaglandin $\mathrm{F}_{2 \mathrm{n}}$ mediates ovarian sterol carrier protein-2 expression during luteolysis Endocrinology 136 4963-4972

McNeilly AS, Crow WJ and Fraser HM (1992) Suppression of pulsatile luteinizing hormone secretion by gonadotrophinreleasing hormone antagonist does not affect episodic progesterone secretion or corpus luteum function in ewes Journal of Reproduction and Fertility 96 865-874

Mamluk R, Chen D-b, Greber Y, Davis JS and Meidan R (1998) Characterization of messenger ribonucleic acid expression for prostaglandin $\mathrm{F}_{20}$ and luteinizing hormone receptors in various bovine luteal cell types Biology of Reproduction 58 849-856

Marsh JM (1975) The role of cyclic AMP in gonadal function. In Advances in Cyclic Nucleotide Research Vol. 6 pp 137-200 Eds P Greengard and GA Robison. Raven Press, New York

McArdle CA and Holtorf A-P (1989) Oxytocin and progesterone release from bovine corpus luteal cells in culture: effects of insulin-like growth factor I, insulin, and prostaglandins Endocrinology 124 1278-1286 
Miller WL (1996) Mitochondrial specificity of the early steps in steroidogenesis Journal of Sleroid Biochemistry and Molecular Biology 55 607-616

Murdoch WJ (1996) Microtubular dynamics in granulosa cells of periovulatory follicles and granulosa-derived (large) lutein cells of sheep: relationships to the steroidogenic folliculo-luteal shift and functional luteolysis Biology of Reproduction 54 1135-1140

Nancarrow CD (1994) Embryonic mortality in the ewe and doe. In Embryonic Mortality in Dontestic Species, pp 79-97 Eds MT Zavy and RD Geisert. CRC Press, Boca Raton, FL

Niswender GD and Nett TM (1994) Corpus luteum and its control in infraprimate species. In The Physiology of Reproduction VoL 1 pp 781-816 Eds E Knobil and JD Neill. Raven Press, Ltd, New York

Niswender GD, Reimers TJ, Diekman MA and Nett TM (1976) Blood flow: a mediator of ovarian function Biology of Reproduction 14 64-81

Niswender GD, Schwall RH, Fitz TA, Farin CE and Sawyer HR (1985) Regulation of luteal function in domestic ruminants: new concepts Recent Progress in Homone Research 41 101-151

Papadopoulos V, Amri H, Boujrad N, Cascio C, Culty M, Garnier M, Hardwick M, Li H, Vidic B, Brown AS, Reversa JL, Bernassau JM and Drieu K (1997a) Peripheral benzodiazepine receptor in cholesterol transport and steroidogenesis Steroids 62 21-28

Papadopoulos V, Amri H, Li H, Boujrad N, Vidic B and Garnier M (1997b) Targeted disruption of the peripheral-type benzodiazepine receptor gene inhibits steroidogenesis in the R2C Leydig tumor cell line Journal of Biological Chemistry $27232129-32135$

Perks CM, Denning-Kendall PA, Gilmour RS and Wathes DC (1995) Localization of messenger ribonucleic acid for insulin-like growth factor I (IGF-I), IGF-II and the type 1 IGF receptor in the ovine ovary throughout the oestrous cycle Endocrinology 136 5266-5273

Pescador N, Soumano K, Stocco DM, Price CA and Murphy BD (1996) Steroidogenic acute regulatory protein in bovine corpora lutea Biology of Reproduction 55 485-491

Peters KE, Bergfeld EG, Cupp AS, Kojima FN, Mariscal V, Sanchez T, Wehrman ME, Grotjan HE, Hamernick DL, Kittok RJ and Kinder JE (1995) Luteinizing hormone has a role in development of fully functional corpora lutea (CL) but is not required to maintain CL function in heifers Biology of Reproduction 51 1248-1254

Rodgers RJ, O'Shea JD and Findlay JK (1983) Progesterone production in vitro by small and large ovine luteal cells Journal of Reproduction and Fertility 69 113-124

Rodgers RJ, Waterman MR and Simpson ER (1986) Cytochromes $\mathrm{P}-450^{\circ}, \mathrm{P} 450^{\text {sec } 17 n}$, adrenodoxin, and reduced nicotinamide adenine dinucleotide phosphate-cytochromé P-450 reductase in bovine follicles and corpora lutea Endocrinology 118 1366-1374

Rodgers RJ, Waterman MR and Simpson ER (1987) Levels of messenger ribonucleic acid encoding cholesterol sidechain cleavage cytochrome P-450, 17 $\alpha$-hydroxylase cytochrome P-450, adrenodoxin, and low density lipoprotein receptor in bovine follicles and corpora lutea throughout the ovarian cycle Molecular Endocrinology 1 274-279

Rodgers RJ, Vella CA, Young FM, Tian XC and Fortune JE (1995) Concentrations of cytochrome $\mathrm{P} 450$ cholesterol side-chain cleavage enzyme and 3ß-hydroxysteroid dehydrogenase during prostaglandin $\mathrm{F}_{2 \mathrm{a}}$-induced luteal regression in cattle Reproduction Fertility Development 7 1213-1216

Spicer LJ, Ireland JJ and Roche JF (1981) Changes in serum LH, progesterone, and specific binding of ${ }^{125} \mathrm{I}-\mathrm{hCG}$ to luteal cells during regression and development of bovine corpora lutea Biology of Reproduction 25 832-841

Sugawara T, Kiriakidou M, McAllister JM, Kallen CB and Strauss JF III (1997) Multiple steroidogenic factor 1 binding elements in the human steroidogenic acute regulatory protein gene $5^{\prime}$-flanking region are required for maximal promoter activity and cyclic AMP responsiveness Biochemistry $367249-7255$

Stocco DM and Clark BJ (1996) Regulation of the acute production of steroids in steroidogenic cells Endocrine Reviezos 17 221-244

Tandeski TR, Juengel JL, Nett TM and Niswender GD (1996) Regulation of mRNA encoding low density lipoprotem receptor and high density lipoprotein-binding protein in ovine corpora lutea Reproduction Ferititity and Development 8 $1107-1114$

Tian XC, Berndtson AK and Fortune JE (1994) Changes in levels of messenger ribonucleic acid for cytochrome P450 sidechain cleavage and $3 \beta$-hydroxysteroid dehydrogenase during prostaglandin $\mathrm{F}_{20}$-induced luteolysis in cattle Biology of Reproduction 50 349-356

Voss AK and Fortune JE (1993a) Levels of messenger ribonucleic acid for cholesterol side chain cleavage cytochrome $\mathrm{P}-450$ and $3 \beta$ hydroxysteroid dehydrogenase in bovine preovulatory follicles decreases after the luteinizing hormone surge Endocrinology $132888-894$

Voss AK and Fortune JE (1993b) Levels of messenger ribonucleic acid for cytochrome $\mathrm{P} 45017$ alpha-hydroxylase and $\mathrm{P} 450$ aromatase in preovulatory bovine follicles decrease after the luteinizing hormone surge Endocrinology 132 2239-2245

Wiltbank MC, Diskin MG and Niswender GD (1991) Differential actions of second messenger systems in the corpus luteum Journal of Reproduction and Fertility Supplentent 43 65-75

Wiltbank MC, Belfiore CJ and Niswender GD (1993) Steroidogenic enzyme activity after acute activation of protein kinase (PK) A and PKC in ovine small and large luteal cells Molecular and Cellular Endocrinology 97 1-7

Wiltbank MC, Shiao TF, Bergfelt DR and Ginther OJ (1995) Prostaglandin $\mathrm{F}_{2 \alpha}$ receptors in the early bovine corpus luteum Biology of Reproduction 52 74-78

Zavy MT (1994) Embryonic mortality in cattle. In Embryonic Mortality in Domestic Species pp 99-140 Eds MT Zavy and RD Geisert. CRC Press, Boca Raton, FL 